\title{
Abstracts
}

\section{P1 IMMUNOABLATION WITH T CELL DEPLETED AUTOLOGOUS PERIPHERAL BLOOD STEM CELL RESCUE PRODUCES COMPLETE REMISSION IN THROMBOCYTOPENIC PURPURA (TTP) RECIDIVANT AND REFRACTORY TO STANDARD TREATMENT}

I. Espigado, J. Rodríguez, M. Carmona, D. Alonso, E. Ríos, J. Pérez-Hurtado, M. Martino, P. Noguerol, M. Vinuesa, R. Parody. Seville, Spain

Background: TTP is a life threatening uncommon condition. Immune mechanisms may play a part in its pathogenesis. First line treatment is based on plasma exchange, and roughly $85 \%$ of cases respond. Refractory and resistant/recidivant forms usually have a poor prognosis despite the association of alternative treatments. There is increasing evidence of the efficacy of high dose immunosuppression treatment in diseases with possible autoimmune pathogenesis.

Patient and methods: In April 1998 a 38 year old woman was diagnosed with severe TTP. She was treated with intensive plasma exchange, achieving complete remission. While she was on a plasmapheresis programme, the disease showed a recidivant and progressive course and became refractory to plasmatic exchange. It was also resistant to steroids, intravenous immunoglobulin, vincristine, and splenectomy. After written informed consent, treatment with cyclophosphamide was started $1 \mathrm{~g} / \mathrm{m}^{2} \times 5$ doses and a sixth dose of 3 $\mathrm{g} / \mathrm{m}^{2}$ followed by G-CSF $(10 \mu \mathrm{g} / \mathrm{kg} /$ day $\times 7$ days $)$ to mobilise haemopoietic progenitor cells. Three cytapheresis procedures were performed. The first two underwent CD $34+$ selection and the third was used as a back up. The patient received conditioning ${ }^{1}$ with cyclophosphamide $50 \mathrm{mg} / \mathrm{kg} \times 2$ days, anti-lymphocyte globulin $10 \mathrm{mg} / \mathrm{kg} /$ day $\times$ 3 days and methylprednisolone $1 \mathrm{~g}$ /day $\times 3$ days. On 18 January 2000 autologous haemopoietic progenitor cells were infused (CD34+ 5.24; CD3 $+0.082 \times 10^{6} / \mathrm{kg}$ ). Toxicity was cardiac (grade 1 ), hepatic (1), mucositis (1), and alopecia. The ANC nadir $(100 / \mu \mathrm{l})$ was on day 4 and the recovery $\left(>0.5 \times 10^{9} / 1\right)$ on day 8 . During the pancytopenia period she had two days of self limited fever. She was transfused with one red cell bag and did not require transfusion with platelets, or parenteral nutrition. She was discharged on day 13, being asymptomatic. Six months after transplant she is in clinical and haematological complete remission, with $100 \%$ Karnofsky index and receiving no treatment. A longer follow up is needed to confirm that she is cured.

Conclusions: (1) Treatment with high doses of immunosuppression and autologous rescue with $\mathrm{T}$ cell depleted haemopoietic progenitor cells may produce complete remission in TTP recidivant and refractory to conventional treatment. (2) To evaluate the efficacy and morbidity of high dose immunosuppression as a treatment for recidivant and/or refractory TTP a pilot study would be needed.

1 Musso M, Porretto F, Crescimanno A, Bondi F, Polizzi V, Scalone R, et al. Successful treatment of resistant thrombotic thrombocytopenic purpura/hemolytic uremic syndrome with autologous peripheral blood stem and progenitor (CD34+) cell transplantation. Bone Marrow Transplant 1999;24:207-9.

\section{P2 IMMUNOABLATION AND T CELL DEPLETED AUTOLOGOUS PERIPHERAL BLOOD STEM CELL RESCUE AS EFFECTIVE TREATMENT FOR LONG TERM PROGRESSIVE RHEUMATOID ARTHRITIS REFRACTORY TO MULTIPLE CONVENTIONAL TREATMENT}

I. Espigado, A. García, J. Rodríguez, A. Valenzuela, M. Carmona, E. Ríos, R. Parody. Seville, Spain

Background: Immunoablation followed by autologous haemopoietic stem cell rescue produces remission in rheumatoid arthritis (RA) refractory to conventional treatment. We report a new case of effective response in a patient diagnosed with RA refractory to conventional treatment.

Patient and methods: A 25 year old woman was diagnosed with seronegative RA in 1991. Her disease had a progressive and recidivant course despite multiple conventional treatments with gold salts, methotrexate, hydroxychloroquine, cyclosporin, sulfasalazine, azathioprine, steroids, and non-steroidal anti-inflammatory drugs. Before transplant she had 20 swollen joints, 14 tender joints, 2 hours of morning stiffness, HAQ 2.87, pain $55 \mathrm{~mm}$ (VAS), patient global severity (PGS-VAS) $89 \mathrm{~mm}$, doctor global severity (DGS-VAS) 83 $\mathrm{mm}$. After signed informed consent, cyclophosphamide $\left(2 \mathrm{~g} / \mathrm{m}^{2} \times 1\right.$ day) and G-CSF $(10 \mu \mathrm{g} / \mathrm{kg} /$ day $\times 7$ days $)$ were given. Two cytapheresis procedures were performed. The product of the first one and part of the second was enriched in vitro with CD34+ selection; the rest of the second was used as a back up. The patient received conditioning with cyclophosphamide $50 \mathrm{mg} / \mathrm{kg} \times 4$ days, anti-lymphocyte globulin 15 $\mathrm{mg} / \mathrm{kg} /$ day $\times 4$ days and methylprednisolone $2 \mathrm{mg} / \mathrm{kg} / \mathrm{d} \times 4$ days. On 2 February 2000, autologous infusion was performed (CD34+ 3.78; $\mathrm{CD} 3+0.027 \times 10^{6} / \mathrm{kg}$ ). Toxicity was nausea, vomiting, renal (grade 1 ), liver (1), mucositis ( 1$)$, and alopecia. The ANC nadir $(0 / \mu \mathrm{l})$ was on day 3 and the recovery $(>500 / \mu \mathrm{l})$ on day 12 . During the aplasia she had self limited gynaecological haemorrhage and an acute bacterial pulmonary infection cured by specific antibiotic treatment. She was transfused with 8 red cell concentrates and 11 single donor platelet units. She required 3 days of parenteral nutrition. She was discharged on day 21. The third month after transplant an evaluation showed $>80 \%$ response of the RA with 3 swollen joints, 2 tender joints, HAQ 2.00 , pain 22, PGS-VAS 49, DGS-VAS 80, and morning stiffness of 15 minutes. She does not require treatment. A longer follow up is needed to know the long term outcome.

Conclusion: (1) Immunoablation produces remission of RA refractory to multiple conventional treatments. (2) Rescue by autologous haemopoietic progenitors may reduce life threatening complications in the early post-transplant period. (3) $\mathrm{T}$ cell depletion of the graft may play a part in the non-autoaggressive post-transplant immune reconstitution.

\section{P3 CD34 POSITIVE SELECTION OF CRYOPRESERVED PERIPHERAL BLOOD STEM CELLS (PBSC) FOR AUTOLOGOUS TRANSPLANTATION IN A PATIENT WITH WEGENER'S GRANULOMATOSIS}

M. Bornhäuser, K.-D. Paul, M. Gahr, H.-G. Nuesslein, M. Meurer, J. Oppermann, C. Pfeiffer, K. Lüthke, H.-E. Schröder, G. Ehninger. Dresden, Cottbus, Germany

Background: There is some debate about the role of $\mathrm{T}$ and $\mathrm{B}$ cell depletion for autologous stem cell transplantation in patients with autoimmune diseases. No clinical study has yet proved the effectiveness of expensive procedures like CD34 positive selection.

Patient and method: Therefore, we decided to design our local protocol with optional CD34 positive selection of autologous PBSC after thawing immediately before the infusion. For this purpose the CliniMACS selection procedure (Miltenyi) was slightly modified using cold buffer solutions and DNAse digestion to prevent cell clumping after thawing of the highly concentrated apheresis product.

A 16 year old male patient with antiproteinase-3 positive Wegener's granulomatosis who had not responded to high dose steroids, cyclophosphamide, and immunoglobulins was included in the trial. At the time of inclusion retro-orbital infiltrates led to progressive impairment of the visus, and a subglottic stenosis caused nocturnal breathing problems. The boy had a massive Cushing's syndrome $(105 \mathrm{~kg})$ and was still receiving methylprednisolone $(60 \mathrm{mg})$. Mobilisation chemotherapy consisted of $4 \mathrm{~g} / \mathrm{m}^{2}$ cyclophosphamide given in two doses. The PBSC harvest of one apheresis $\left(6 \times 10^{6} / \mathrm{kg} \mathrm{CD} 34+\right.$ cells) was frozen in two portions. The patient's symptoms improved for several weeks. Nevertheless, progressive disease occurred 2 months later and high dose chemotherapy with $200 \mathrm{mg} / \mathrm{kg}$ cyclophosphamide and $10 \mathrm{mg} / \mathrm{kg}$ ATG Merieux was performed. 1.5 $\times 10^{6} / \mathrm{kg}$ CD $34+$ cells could be infused after CD34+ selection and the patient received post-transplant G-CSF starting on day 6 . Neutrophil and platelet recovery was fast, occurring within 10 and 6 days, respectively.

Results: Ten months after the transplant the patient is alive with stable disease. Antiproteinase- 3 titres have not decreased significantly but the steroid dose could be decreased to $10 \mathrm{mg} /$ day.

Conclusion: The option to perform CD34+ selection of PBSC after cryopreservation could be helpful for randomised studies addressing the role of $\mathrm{T}$ and $\mathrm{B}$ cell depletion in this setting. 
P4 INFILTRATE ANALYSIS OF RHEUMATOID SYNOVIAL TISSUE BEFORE AND AFTER HIGH DOSE CHEMOTHERAPY AND AUTOLOGOUS STEM CELL TRANSPLANTATION

R.J. Verburg, R. Flierman, E.W.N. Levahrt, F. van den Hoogen, F.C. Breedveld, J.M. van Laar. Leiden, Nijmegen, Netherlands

Objective: To investigate the effects of high dose chemotherapy (HDC) and autologous stem cell transplantation (ASCT) on the synovial infiltrate in rheumatoid arthritis.

Methods: 8 patients with erosive, refractory, progressive rheumatoid arthritis, were treated with HDC (cyclophosphamide $200 \mathrm{mg} / \mathrm{kg}$ ) and CD34 enriched selected ASCT. Biopsy specimens of synovial tissue from a clinically affected knee were obtained by arthroscopy before and three months after HDC and ASCT. Immunohistochemistry was performed and blindly scored on a five point scale $(0-4)$ using mAbs specific for the following markers: CD3, CD4, CD8, CD25, CD27, CD45RA, CD45RO, CD45RB, CD19, CD20, CD22, CD38, CD5, CD68, HLA-DR, CD62L, CD62E, CD56, and CD55.

Results: There were no statistically significant differences (Wilcoxon's signed rank test) when the results before and after transplantation were compared. However, when patients were divided into clinical responders (ACR $>50 \%, n=5$ ) and non-responders (ACR $<20 \%, \mathrm{n}=3$ ) statistically significant differences for several $\mathrm{T}$ cell markers were found (table 1).

Table 1 Mean (SD) histological score

\begin{tabular}{lllllll}
\hline & \multicolumn{2}{l}{ Responders } & & \multicolumn{2}{l}{ Non-responders } & \\
\cline { 2 - 3 } & Before & After & & Before & After & \multirow{2}{*}{ p Value } \\
\hline CD 3 & $2.8(0.5)$ & $1.3(2.3)$ & & $1(1.4)$ & $1.7(2.1)$ & 0.06 \\
CD 27 & $3(0.8)$ & $0.3(0.6)$ & & $1(0.8)$ & $1.7(2.1)$ & 0.05 \\
CD 45 RA & $2.3(0.9)$ & $0.7(1.2)$ & & $0.5(1)$ & $1.6(2.1)$ & 0.03 \\
CD 45 RO & $3.4(0.5)$ & $0.7(1.2)$ & & $1.8(1.6)$ & $2(2)$ & 0.04 \\
CD 45 RB & $3.2(0.8)$ & $1(1.7)$ & & $2(1.6)$ & $2(2)$ & 0.05 \\
\hline
\end{tabular}

^Mann-Whitney U test.

Clinical and immunohistochemical responses were predicted by CD27 ( $p=0.016)$, CD 45RO $(p=0.003)$, and CD45RB $(p=0.047)$ infiltration before treatment.

Conclusions: There was a statistically significant difference $(p<0.05)$ between clinical responders and non-responders for the decrease in infiltration of CD45RA+ and CD45RO+ cells after HDC and ASCT. CD27, CD45RO, and CD45RB appear to be useful markers to predict clinical response.

\section{P5 AUTOLOGOUS STEM CELL TRANSPLANTATION (ASCT) AFTER HIGH DOSE IMMUNOSUPPRESSIVE (HDI) TREATMENT IN RHEUMATOID ARTHRITIS (RA): CLINICAL AND PATHOLOGICAL CORRELATIONS}

R.J. McKendry *, H.L. Atkins, L.B. Huebsch, J. Karsh, M. Senterman, S. Robertson Ottawa, Canada

Patient and methods: We report a 24 month follow up of a 22 year old woman with a 5 year history of polyarticular RA receiving HDI followed by ASCT, according to an REB approved protocol. At baseline, treatment with 4 DMARDs had failed and she had 42 tender and 12 swollen joints, ESR $58 \mathrm{~mm} / 1 \mathrm{st} \mathrm{h}, \mathrm{CRP} 124 \mathrm{mg} / \mathrm{l}$. Twelve weeks after stem cell mobilisation (SCM) (cyclophosphamide $8.1 \mathrm{~g}$ and G-CSF $\times 8$ days) and stem cell (SC) collection these disease activity markers had improved by $50 \%$. This partial remission lasted for 6 months. In line with the protocol HDI and ASCT were delayed until she no longer met the ACR 50 response criteria ( 8 months). HDI (cyclophosphamide $14.0 \mathrm{~g}$ and rATG $340 \mathrm{mg}$ ) was followed by a CD34 cell enriched and $\mathrm{T}$ cell depleted (3.72 log) SC rescue. No antirheumatic drugs have been used since SCM. Clinical and laboratory measures and 5 serial arthroscopic biopsies provide clinicopathologic correlations (table 2).

Results: Histologically, the synovium showed marked diffuse chronic synovitis before and 13 weeks after SCM. There was a dramatic reduction in the inflammatory infiltrate and synovial hyperplasia at 9 weeks after HDI/ASCT, with the synovium returning to a normal histologic appearance. Since then, there has been a slight increase in mononuclear inflammatory cells. At 32 weeks after $\mathrm{HDI} / \mathrm{ASCT}$, the CD45RO positive T cells show a striking perivascular localisation, with $\mathrm{CD} 8$ positive cells predominating in that region.
Table 2

\begin{tabular}{|c|c|c|c|c|c|c|c|c|}
\hline & \multirow[b]{2}{*}{ Baseline } & \multicolumn{3}{|l|}{$S C M$} & \multicolumn{4}{|c|}{$H D I / A S C T$} \\
\hline & & $W k 8$ & Wk 16 & Wk 27 & $W k 7$ & Wk 20 & Wk 51 & Wk 69 \\
\hline Tender & 42 & 30 & 20 & 28 & 3 & 1 & 3 & 7 \\
\hline Swollen & 12 & 9 & 5 & 9 & 2 & 2 & 0 & 0 \\
\hline ESR & 58 & 10 & 17 & 15 & 7 & 7 & 5 & 6 \\
\hline
\end{tabular}

The CD4 positive cells are fewer in number and more diffusely scattered. At 59 weeks after HDI/ASCT there has been a mild increase in inflammatory cells, mainly the CD45RO positive T cells.

Conclusions: (1) The intensity of the synovitis using synovial histopathology correlates with clinical and laboratory markers. (2) Hyperplasia of synoviocytes is reversible. (3) Perivascular localisation of CD $45 \mathrm{RO}$ positive cells heralds the recurrence of a synovial inflammatory infiltrate. (4) The use of cyclophosphamide for both mobilisation and HDI may produce a more durable remission, particularly if the HDI/ASCT is delayed until the initial, partial remission from the SCM wanes.

P6 LONG TERM FOLLOW UP OF HIGHLY SELECTED AUTOLOGOUS STEM CELL TRANSPLANTATION (ASCT) IN SEVERE RHEUMATOID ARTHRITIS WITH STUDIES OF PERIPHERAL BLOOD AND SYNOVIAL LYMPHOCYTE RECONSTITUTION

S. Bingham, D. Veale, R. Reece, U. Fearon, J. Isaacs, D. McGonagle, J Snowden, G. Morgan, P. Emery. Leeds, Leicester, UK

Objective: To assess the long term safety and efficacy of highly selected ASCT for the treatment of severe RA.

Method: Mobilisation: $2 \mathrm{~g} / \mathrm{m}^{2}$ cyclophosphamide and G-CSF; graft manipulation: positive $\mathrm{CD} 34+$ selection and negative $\mathrm{T}$ cell selection (>5 log $\mathrm{T}$ cell depletion); conditioning: $200 \mathrm{mg} / \mathrm{kg}$ cyclophosphamide. Six patients with RA (1987 ARA criteria) transplanted ( 3 female, 3 male, age 24-55, disease duration 3-17 years, number of failed DMARDs 4-8). Peripheral blood lymphocyte (PBL) subsets analysed at baseline, 1 month, and then three monthly after ASCT. Arthroscopy of large affected joint at baseline, three months after ASCT, and relapse.

Results: Minimal transplant related toxicity: 3 mild neutropenic sepsis, one hickman line infection, and one PUO and transient pancytopenia at one month. Follow up is from 6 to 24 months. All patients responded initially $(1 \times$ ACR $70,2 \times$ ACR $50,3 \times$ ACR 20$)$. All patients relapsed (at 1.5-9 months) and treatment was started with cyclosporin. One patient subsequently achieved ACR remission, two ACR 50, one ACR 20, one improved but did not satisfy ACR response criteria, one did not respond. All patients continue to have low CD4 PBL even at relapse despite a marked increase in synovial CD4 infiltration at relapse in patient 2.

Conclusion: Highly selected ASCT is safe and has short term efficacy. Five patients responded to cyclosporin after relapse when their disease had previously been refractory to conventional treatment, suggesting an immunomodulatory effect. All patients had prolonged peripheral lymphocyte depletion but no serious infections occurred. T lymphocyte infiltration of the synovium was seen at relapse despite peripheral lymphocyte depletion, suggesting $\mathrm{T}$ cell mediated disease even in established RA.

This work is funded by the ARC.

\section{P7 QUALITY OF LIFE OF PATIENTS WITH MULTIPLE SCLEROSIS AFTER AUTOLOGOUS PERIPHERAL STEM CELL TRANSPLANTATION}

A.A. Novik, T.I. Ionova, L.V. Chelombit, P.I. Denisov, V.Y. Melnichenko, A.V. Kishtovich. St Petersburg, Russia

Background: Multiple sclerosis (MS) is neurological progressive disease with great detriment to the patient's quality of life (QoL). QoL is one of the important outcomes of MS treatment. Autologous peripheral stem cells transplantation (APSCT) is the new treatment strategy for patients with MS. The QoL of patients with MS after APSCT has not yet been studied.

Objective: To monitor QoL of three patients with MS after APSCT, treated at the BMT Unit of the Clinic of Haematology and Clinical Immunology, Russian Military Medical Academy (St Petersburg). 
Method: QoL was assessed by QoL questionnaires: one particularly for patients with BMT (FACT-BMT) and another for patients with MS (FAMS). Both questionnaires were translated, adapted, and validated together with Evanston CORE (Evanston, USA). The questionnaires were administered before PSCT and at discharge, and 3, 6, 8, and 12 months after APSCT.

Results: All three APSCT were clinically successful. Patients were discharged on the 42nd, 44th, and 56th day after APSCT. QoL parameters by FACT-BMT of patient 1 (48 years old, spinal type, primary progredient process, stage of decompensation, APSCT 18 May 2000) 30 days after APSCT were compared with the parameters before transplantation, showing an improvement of physical and emotional functioning. All QoL parameters by FAMS improved after APSCT as compared with the parameters before transplantation. General QoL showed a 2.5-fold improvement.

QoL parameters by FACT-BMT of patient 2 (21 years old, cerebral-spinal type, primary progredient remitting process, stage of remission, APSCT 22 March 2000) were stable within 3 months after transplantation. All QoL parameters by FAMS improved during the 3 months after APSCT.

All QoL parameters of patient 3 (48 years old, cerebral-spinal type, secondary progredient process, stage of decompensation, APSCT 31 May 1999) improved in the 8 months after transplantation, with further improvement at 12 months.

Conclusions: APSCT produces an improvement in the QoL of patients with MS. QoL parameters affected by MS improve within 3 months after APSCT, with a tendency towards significant improvement of physical, psychological, and social wellbeing one year after APSCT.

\section{P8 HIGH DOSE MELPHALAN WITH STEM CELL SUPPORT FOR THE REFRACTORY IMMUNE THROMBOCYTOPENIC PURPURA (ITP): A CASE REPORT}

I. Lisukov, S. Sizikova, A. Kulagin, I. Kruchkova, A. Gilevich, H. Chernykh, O. Leplina, V. Kozlov. Novosibirsk, Russia

Background: Recently, high dose chemotherapy (HDC) followed by autologous stem cell transplantation has been proposed as a new strategy for the treatment of severe autoimmune diseases.

Patient and methods: A 17 year old young man developed ITP in November 1998 (skin haemorrhage, mucous membrane bleeding, platelet count $\left.8 \times 10^{\circ} / 1\right)$. He was treated with prednisone $(1 \mathrm{mg} / \mathrm{kg})$ over 16 weeks with good response. In March 1999 a relapse occurred. Splenectomy was performed and prednisone was continued. A second complete response was seen, but in September 1999 the patient was admitted to our hospital with severe purpura, epistaxis and urinary bleeding. Platelet count was $12 \times 10^{9} / 1$. After ethics committee approval and informed consent in November 1999 HDC with Melphalan $120 \mathrm{mg} / \mathrm{m}^{2}$ followed by autologous PBSCT was performed. PBSC were mobilised with G-CSF (filgrastim) $10 \mu \mathrm{g} / \mathrm{kg} /$ day for 5 days. After PBSC reinfusion $5 \mu \mathrm{g} / \mathrm{kg} \mathrm{G}-\mathrm{CSF}$ was given subcutaneously daily.

Results: Grade I mucositis and enteropathy were developed. FUO appeared on day 10 and responded successfully to amphotericin B and vancomycin. Haemopoietic recovery was delayed. ANC reached $0.5 \times 10^{9} / 1$ on day 51 . Platelet counts reached $50 \times 10^{9} / 1$ on day 74 . Complete response was achieved on day +85 (platelet count $165 \times$ $\left.10^{9} / 1\right)$. The patient remains in complete remission after 8 months of follow up. Maintenance treatment is prednisone $10 \mathrm{mg} /$ day.

Conclusion: HDC followed by autologous stem cell transplantation may be an effective treatment for refractory ITP. Long term follow up will be necessary to demonstrate whether the remission is persistent.

\section{P9 AUTOLOGOUS HAEMOPOIETIC STEM CELL TRANSPLANTATION (HSCT) FOR PARANEOPLASTIC CEREBELLAR DEGENERATION: A CASE REPORT}

M.-A. Gonzalez-Lopez, J.-M. Paz Carreira, E. Lavilla, J. Arias, A. de Andres, N. Diaz, R. Pego, F. Graus. Lugo, Barcelona, Spain

Patient and methods: A 17 year old man, previously diagnosed with Hodgkin's disease (HD) mixed cellularity stage IV-B, was admitted to the hospital with a cerebellar syndrome. He had received chemotherapy (6 cycles of ABVD) and mantle radiotherapy, obtaining a complete remission of $\mathrm{HD}$. One year after the diagnosis he developed ataxia, nistagmus, dysarthria, and found it impossible to stand and walk. Relapse of HD was ruled out. CSF analyses showed lymphocytic leucocytosis and an MRI of the head was normal. Anti-Tr antibodies specific for Purkinge cells were demonstrated in the serum and CSF, so diagnosis of paraneoplastic cerebellar degeneration (PCD) associated with HD was established.

The patient received high dose gammaglobulins, resulting in only a slight improvement. Treatment with autologous haemopoietic stem cell transplantation (HSCT) was performed:

- Mobilisation: cyclophosphamide $2 \mathrm{~g} / \mathrm{m}^{2}$ and G-CSF

- Positive CD-34 selection

- Conditioning regimen: CBV

- Infusion $2.41 \times 10^{6} / \mathrm{kg}$ TNC and $2.2 \times 10^{6} / \mathrm{kg} \mathrm{CD}-34$

- Complications: mild mucositis, gastrointestinal toxicity and coagulase-negative staphylococcus bacteraemia.

- Haematological recovery: PMN $>0.5 \times 10^{9} / 1$ on day 13 and platelets $>0 \times 10^{9} / 1$ on day 19

Results: Fourteen months after HSCT there is no progression of the disease, marked improvement of dysarthria and an ability to walk with aid, and the anti-Tr titre is $1 / 500$ (previous $1 / 2000$ ).

Conclusions: $\mathrm{HD}$ is the $3 \mathrm{rd}$ cause of PCD, after lung and ovarian carcinoma. It is more common in young men, and while being in complete remission improvement has been occasionally reported with immunoglobulins, plasmapheresis, clonazepam, or corticosteroids. HSCT was used without immediate complications and a positive response in the usually rapid evolution of this disease.

\section{P10 AUTOLOGOUS STEM CELL TRANSPLANTATION FOR MULTIPLE SCLEROSIS IN RUSSIA}

A. Novik, M. Odinak, V. Melnichenko, S. Voloshin, G. Bisaga, A. Novitsky, O. Uspenskaja. St Petersburg, Russia

Patients and methods: In 1999-2000 in the Bone Marrow Transplantation Unit of the Military Medical Academy (St Petersburg) three autologous stem cell transplantations (ASCT) were carried out for patients with multiple sclerosis (MS). All the patients were women, aged 21-48 years, with considerable disability. The Kurtzke Expanded Disability Status Scale (EDSS) was used for clinical neurological assessments. Two patients had secondary progredient subtype (EDSS 5 and 7.5 respectively) and the third patient had a primary remitting subtype of MS (EDSS 4). According to the protocol stem cells were mobilised by G-CSF $10 \mathrm{mg} / \mathrm{kg}$ subcutaneously; leukaphereses on days $4,5,6$; conditioning regimen BEAM and ATGAM (Upjohn) $60 \mathrm{mg} / \mathrm{kg}$. Stem cells were reinfused on day 0. For shortening myelosuppression G-CSF were used at $5 \mathrm{mg} / \mathrm{kg}$ subcutaneously; a 500 neutrophil/ml level was achieved on day 11 or 12 . Platelet level was $50 \times 10^{9} / 1$ on days $22-28$.

Results: On day 30 after ASCT two patients improved by 0.5 and 1 EDSS points respectively. One improvement was striking and of great importance to the patient. The third patient had no changes according to the EDSS and remained stable.

All patients had achieved complete remission between 3 and 15 months.

\section{P11 TREATMENT OF SEVERE RESISTANT AUTOIMMUNE CYTOPENIAS WITH CAMPATH-1H}

F. Willis, J Marsh, D. Bevan, S. Killick, G. Lucas, R. Griffiths, W. Ouwehand, G. Hale, H. Waldmann, E. Gordon-Smith. London, Bristol, Cambridge, Oxford, UK

Background: Haemopoietic stem cell treatment has been proposed for severe resistant autoimmune cytopenias. An alternative and safer option may be the monoclonal antibody Campath- $1 \mathrm{H}$, which may reset the immune system and avoid the need for total immune ablation.

Patient and methods: Fifteen patients with resistant and life threatening autoimmune cytopenias received Campath-1H. Patients had autoimmune neutropenia (AIN, $n=3$ ); autoimmune haemolytic anaemia (AIHA, $n=2$ ); pure red cell aplasia (PRCA, $n=2)$; ITP, $n=1$; AIHA and ITP, $n=3$; autoimmune pancytopenia, $n=2$; ITP and AIN, $\mathrm{n}=2$. Campath $-1 \mathrm{H} 10 \mathrm{mg}$ daily was given as an IV infusion for 10 days. Half the patients also received low dose cyclosporin (CSA) after Campath-1H to help prevent relapse.

Results: Campath-1H was well tolerated apart from first day reactions and intracranial haemorrhage on day 4 in a patient with ITP and active, generalised bleeding. Two of 3 patients with AIN had a 
sustained response. All 5 evaluable patients with ITP responded but relapsed needing further prednisolone, CSA or further Campath-1H. Both patients with PRCA and both with AIHA responded. Despite profound and persistent CD4+ lymphopenia, there were no serious viral or opportunistic infections and no EBV lymphoproliferative disease. Ten patients are alive at a median of 14 months (range 5-46). New autoantibodies were seen after Campath- $1 \mathrm{H}$ in two patients (one with positive anticardiolipin (ACLA), anti-thyroid antibodies and later Guillain-Barré syndrome, and one with positive ACLA and weak antinuclear antibody).

Conclusion: Campath-1H represents an alternative option for patients with resistant and life threatening autoimmune cytopenias and further prospective studies are warranted in a larger number of patients.

\section{P12 HIGH DOSE CHEMOTHERAPY WITH STEM CELL RESCUE IN SYSTEMIC SCLEROSIS}

J.B. Kuemmerle-Deschner, T. Klingebiel, J. Ihle, U. Holzer, D. Niethammer, G.E. Dannecker. Tübingen, Germany

Background: Systemic sclerosis (SSc) is an autoimmune disease characterised by fibrosis and microvascular occlusion. At present, there is no cure for this disease.

Patient and method: A 19 year old woman was diagnosed with progressive SSc type II, suffering within 4 years from rapidly progressing skin disease (skin score 35), involvement of the gastrointestinal tract, heart, and lungs despite immunosuppressive treatment, including azathioprine, prednisone, and cyclophosphamide (Cy). Several prognostic factors, such as rapid progress of disease, presence of anti-Scl-70-antibodies, and resistance to conventional treatment, indicated a bad prognosis and led therefore to a high dose $\mathrm{Cy}$ treatment followed by stem cell rescue.

Treatment regimen: stem cell mobilisation, Cy $\left(4 \mathrm{~g} / \mathrm{m}^{2}\right)$ and G-CSF $(10 \mu \mathrm{g} / \mathrm{kg})$; conditioning: anti-lymphocyte globulin $(4 \times 15 \mathrm{ml} / \mathrm{kg})$ and Cy $(4 \times 50 \mathrm{mg} / \mathrm{kg})$; stem cell rescue: $5.67 \times 10^{6} \mathrm{CD} 34+$ progenitor cells/ $\mathrm{kg}, 0.62 \times 10^{4} \mathrm{CD} 3+\mathrm{T}$ cells $/ \mathrm{kg}$.

Results: The post-transplantation period was without complications. One patient with infection WHO grade II was treated successfully with antibiotics. On day 100 after stem cell treatment, skin score (25.5), palm closure, and mouth opening were markedly improved. Surprisingly, nail bed capillary microscopy showed newly developing capillaries. However, a relapse occurred thereafter with the skin score increasing again and an increase in procollagen III peptide $(1.7 \mathrm{E} / \mathrm{ml})$. Low dose steroid treatment was introduced (prednisone $10 \mathrm{mg} /$ day), resulting in improvement of the clinical status. On day 250 the skin score was 19 and procollagen III was $0.9 \mathrm{E} / \mathrm{ml}$, indicating reduced disease activity.

Conclusion: Stem cell rescue after high dose chemotherapy is a promising new treatment option in patients with systemic sclerosis resistant to conventional treatment.

\section{P13 CURE OF ANTIPHOSPHOLIPID SYNDROME BY CAMPATH MAB T CELL DEPLETED STEM CELL ALLOGRAFT}

M.O. Musa, M. Al Jurf, E. Sahovic, R. Nounou, D. Spence. Riyadh, KSA; Abu Dhabi,UAE

Patient and methods: A 16 year old schoolboy presented in March 1993 with fever and bruises. He was found to have AML. He received induction and consolidation using standard regimens. Awaiting HSCT, the patient developed in succession a unilateral sterile exudative pleural effusion, which spontaneously resolved, an episode of localised ischaemic retinal necrosis of the left eye, an unexplained episode of transient generalised erythematous maculopapular skin rash, and a prolonged PTT from a lupus inhibitor. The cardiolipin (aCL), antinuclear (ANA), and DNA Abs were all negative at this stage. The patient received an allo HSCT from his brother in February 1994. The conditioning regimen used was cyclosphosphamide and total body irradiation. He received Campath mAbs for GVHD and graft rejection prophylaxis. Campath-IG was intravenously administered before allografting, while the graft itself was subjected to mononuclear cell depletion using Campath-1M mAb. No further immunosuppression was given.

Results: He had a smooth clinical course after HSCT, but developed severe ITP 4 months later. The platelet count dropped to $2 \times 10^{9} / 1$, the haemoglobin to $77 \mathrm{~g} / 1$, with an indirect bilirubin of 28 $\mu \mathrm{mol} / 1$. No red cell fragments were observed and the DCT was negative. The bone marrow showed hypercellular normal haemopoietic activity. For the first time we noted a strongly positive IgM aCL: 93 $\mathrm{mPLU} / \mathrm{ml}$ (normal $<12.5$ ) and a positive ANA titre $1 / 80$ with speckled pattern. The DNA Ab was slightly positive $5 \mathrm{IU} / \mathrm{ml}$ (normal 1-4), and the $\mathrm{CH}_{5}$ was low: $284 \mathrm{O} / \mathrm{ml}$ (normal 345-485). He received prednisolone for 2 months and the blood counts improved to normal. 18 months after HSCT all serological evidence of autoimmunity and the prolongation of the PTT completely disappeared. Currently, more than 6 years after HSCT, the patient is free of leukaemia and autoimmune manifestations, with complete haemopoietic chimerism demonstrated by VNTRs.

Conclusion: Allogeneic HSCT has a proven curative potential for severe AIDs. Autografts, although less effective, are preferred owing to their reduced toxicity. Apart from being effective in the treatment of AIDs, Campath mAb reduces allo HSCT related toxicity and produces a better outcome by depleting both $\mathrm{T}$ and B cells. Graft failure can be overcome by increasing stem cell dose. We advocate the Campath $\mathrm{mAb}$ as a step towards safer allografts for AIDs.

\section{P14 STEM CELL TREATMENT IN INFLAMMATORY MYOPATHIES: PROPOSALS FOR PATIENT SELECTION}

J.M. Grau, M. Laguno, M. Perea. Barcelona, Spain

Idiopathic inflammatory myopathies (IIM) include a heterogeneous group of autoimmune diseases (AD). Polymyositis (PM), dermatomyositis (DM) and inclusion body myositis (IBM) are the three major categories, with a fourth group that includes myositis overlap syndromes associated with systemic sclerosis, rheumatoid arthritis, Sjögren's syndrome, and other diseases. Although immunosuppresive and immunomodulatory treatments are used for treatment with considerable success in some cases, other may be severe and refractory to conventional treatment. Autologous stem cell treatment (ASCT) has been considered as an experimental treatment in severe and refractory $\mathrm{AD}$

Patient selection is one of the major challenges in this field. In general terms the patient should have active $\mathrm{AD}$ which is resistant to current treatment or, alternatively, current treatments cause excessive toxicity. In addition, the patient should be able to tolerate the risks of high dose treatment. In our experience in a single institution with 167 cases of IIM followed up for the past 22 years and after taking account of the outcomes (mortality rates, relapses, and complications), our proposal criteria for ASCT are the following: polymyositis: age 18-60; unequivocal diagnosis (after carefully ruling out IBM and limb girdle muscular dystrophies); detection of antibodies against signal recognition particles, and refractory to a combination treatment (prednisone + cytotoxic drug) for 24 months, including at least six cycles of IV gammaglobulins. Dermatomyositis: age 18-60; unequivocal diagnosis; exclusion of an associated neoplasia; and at least one out of the three: refractory to treatment as in PM, disease relapse during treatment within 36 months after diagnosis, or interstitial lung disease. Exclusion criteria for both PM and DM are seropositivity for HIV, pregnancy, and advanced myositis (based on muscle strength, imaging, and functional scale of activities of daily living). When these recommendations are followed, about $5 \%$ of patients with idiopathic DM and $2 \%$ of those with PM will be candidates for ASCT in our experience.

Supported by FIS 99/0231 and Comissionat per a Universitats i Recerca de la Generalitat de Catalunya 00279 .

\section{P15 AUTOLOGOUS STEM CELL TRANSPLANTATION IN A PATIENT WITH PSORIATIC ARTHROPATHY}

M. Mohren, C. Amberger, T. Daikeler, I. Guenaydin, L. Kanz, I. Koetter. Tübingen, Germany

Background: Young patients with psoriatic arthropathy with extensive joint involvement have a bad prognosis and may show a refractory course. Of particular concern are long term side effects of disease modifying antirheumatic drugs (DMARDs) and secondary diseases due to chronic inflammation such as paraproteinaemia or amyloidosis. High dose immunosuppression with autologous stem cell transplant offers a new approach to obtain long term remissions or even cure in patients with autoimmune diseases. To our knowledge no patients with psoriatic arthropathy have undergone this procedure so far. 
Patient and methods: A 33 year old patient with mutilating psoriatic arthropathy refractory to treatment, first diagnosed in 1983, and monoclonal gammopathy of unknown significance of the $\operatorname{IgA} \kappa$ type.

Treatment: Mobilisation of stem cells with cyclophosphamide (Cy) $4 \mathrm{~g} / \mathrm{m}^{2}$ and G-CSF $5 \mu \mathrm{g} / \mathrm{kg}$. Stem cell apheresis and T cell depletion using the CliniMacs column. Product: $11.38 \times 10^{6} \mathrm{CD} 34+$ cells $/ \mathrm{kg}$. High dose immunosuppression with Cy $50 \mathrm{mg} / \mathrm{kg}$ from day -5 to day -2 , anti-thymocyte globulin (ATG) $20 \mathrm{mg} / \mathrm{kg}$ day -4 to day -1 and retransfusion of $5.21 \times 10^{6} \mathrm{CD} 34+$ cells day 0 .

Further course: acute exacerbation of the patient's arthritis while receiving G-CSF for stem cell mobilisation. Granulocytes 1000/ $\mu$ lat day 19 (only after use of G-CSF starting on day 15), platelets $>2 \times 10^{4} / \mu \mathrm{l}$ at day 21 . Complications: fever $39.1^{\circ} \mathrm{C}$ on day 11 without evidence of an infectious focus, nausea, mucositis, and diarrhoea grade $1 \times 3$ days. No bleeding.

Results: Fast regression of joint swelling and pain within 3 days after the start of high dose immunosuppression, during the further course no complaints and without any DMARDs and/or NSAIDs for a period of 15 months now. Despite a persistent low CD4 count no infectious complications, and no evidence of CMV reactivation. Normal immunofixation within 6 months after treatment.

Conclusion: High dose immunosuppression with autologous stem cell transplantation was effective in our patient with treatment refractory psoriatic arthropathy. The procedure was tolerated without severe toxicity. Owing to possible exacerbation of arthritis the use of G-CSF for stem cell mobilisation can be problematic. The long term effects need to be awaited, particularly because immune reconstitution has not occurred in our patient so far.

\section{P16 HIGH DOSE IMMUNOSUPPRESSION WITH AUTOLOGOUS STEM CELL SUPPORT OF A PATIENT WITH REFRACTORY WEGENER'S GRANULOMATOSIS (WG)}

T. Daikeler, M. Mohren, C. Amberger, M. Soekler, C. Erley, T. Risler, L. Kanz, I. Koetter. Tübingen, Germany

Background: WG is a systemic vasculitis mainly affecting lungs, nasal sinus, and kidneys. Treatment consists of cyclophosphamide (Cy) and steroids according to Fauci's protocol. Cumulative Cy doses greater than $30 \mathrm{~g}$ are quickly reached. Subsequently, there is a high risk for secondary malignancies. Single shot high dose Cy treatment with autologous stem cell support might be an alternative treatment for patients otherwise requiring long term immunosuppression with oral Cy.

Methods: We report on a 33 year old woman who had had WG since 1988. Cyclosporin A (CSA) and Mycophenolatmofetil were given as host versus graft reaction prophylaxis. The patient still needed additional immunosuppression with IV pulse Cy. Having reached a cumulative $\mathrm{Cy}$ dose of $100 \mathrm{~g}$ and taking into account increasing cANCA titres with relapsing pulmonary granulomas, high dose immunosuppressive treatment was applied. After stem cell mobilisation with Cy $\left(4 \mathrm{~g} / \mathrm{m}^{2}\right)$ and G-CSF $5 \mu \mathrm{g} / \mathrm{kg}$ body weight, apheresis with $\mathrm{T}$ cell depletion using the CliniMacs device yielded $2.82 \times 10^{6} \mathrm{CD} 34+$ cells $/ \mathrm{kg}$ body weight. High dose immunosuppression with Cy $50 \mathrm{mg} / \mathrm{kg}$ body weight and ATG $5 \mathrm{mg} / \mathrm{kg}$ body weight on days 1-4 was performed, followed by reinfusion of the purified stem cells.

Result: Soon after stem cell mobilisation with Cy the patient improved. An $x$ ray examination showed regression of the pulmonary infiltrates. However, five months later, the cANCA titre was raised at $1 / 500$. Subsequently, high dose treatment was performed. For protection of the renal graft, immunosuppression with CSA was continued. Another 5 months later, bone marrow aplasia with fever occurred. Serologically and by PCR, an EBV reactivation was diagnosed. Under treatment with ganciclovir and IV immunoglobulins, the EBV infection was controlled. Since then the patient remains in remission without any sign of disease activity (10 months now).

Discussion: High dose immunosuppression with autologous stem cell support was effective in our patient with severe refractory WG. In vivo and in vitro $\mathrm{T}$ cell depletion as performed here leads to longlasting suppression of CD4+ T cells. Eleven months after treatment the $\mathrm{CD} 4+\mathrm{T}$ cells are not completely recovered. It is not yet known whether the disease remission will continue after immune reconstitution. This case suggests an involvement of $\mathrm{T}$ cellular autoimmunity in the pathogenesis of WG. It has to be considered that the suppression of $\mathrm{T}$ cells bears the risk of life threatening opportunistic infections as seen in our patient.
P17 TREATMENT OF CHRONIC INFLAMMATORY DEMYELINATING POLYRADICULONEUROPATHY (CIDP) WITH HIGH DOSE IMMUNOSUPPRESSIVE TREATMENT USING CYCLOPHOSPHAMIDE WITH AUTOLOGOUS HAEMOPOIETIC STEM CELL RESCUE

F. Ciceri, G. Magnani, E. Zappone, P. Servida, P. Corradini, M. Bregni, G. Comi, M.G. Roncarolo, C. Bordignon. Italy

Background: Chronic inflammatory demyelinating polyradiculoneuropathy (CIDP) is considered to be an autoimmune disorder Current treatment regimens leave $4-30 \%$ of patients with CIDP with moderate or severe disability. Conventional dose immunosuppressive treatment has had limited success in halting disease progression in treatment resistant patients. It has been proposed that high dose immunosuppressive treatment using cyclophosphamide with autologous haemopoietic stem cell rescue may be an effective treatment for severe autoimmune diseases.

Methods: We designed a study to test in patients with severe autoimmune disorder the toxicity and efficacy of a myeloablative regimen of cyclophosphamide $50 \mathrm{mg} / \mathrm{kg} \times 4$. Autologous haemopoietic stem cells were mobilised with cyclophosphamide $4 \mathrm{~g} / \mathrm{m}^{2}$ and G-CSF $5 \mu \mathrm{g} / \mathrm{kg}$. A total of $>5 \times 10^{6} \mathrm{CD} 34$ cells $/ \mathrm{kg}$ were stored before proceeding to the conditioning treatment.

Case report: The 36 year old male patient had classic progressive CIDP which started in 1988 with progressive weakness of the arms and legs. Previous treatment included corticosteroids, intravenous immunoglobulins, and interferon $\beta$ 1a with partial control of the progression of the disease. During the past year the disease worsened despite the high dose immunoglobulins.

HSC mobilisation required 2 apheresis procedures to collect and store $>5 \times 10^{6} \mathrm{CD} 34$ cells $/ \mathrm{kg}$. The conditioning regimen has been well tolerated and caused only gastrointestinal side effects < grade II. No life threatening regimen related toxicity or infections have been encountered in the early period after transplant. Engraftment was rapid and the ANC was $<500 / \mu 1$ for 9 days, platelet counts $<2 \times 10^{4} / \mu 1$ for 7 days.

With follow up of 6 months there has been no evidence of disease progression. The patient experienced a sustained clinical improvement with a decrease of motor disability. Motor nerve conduction studies measured before and 6 months after treatment did not show significant changes.

Conclusion: With follow up of 6 months, clinically important improvement was observed in one patient with CIDP after HDIT using cyclophosphamide with autologous haemopoietic stem cell rescue. HDIT should be considered in CIDP patients with progressive disease under conventional treatments.

\section{P18 AUTOLOGOUS PERIPHERAL BLOOD STEM CELL TRANSPLANTATION FOR THE TREATMENT OF SYSTEMIC LUPUS ERYTHEMATOSUS: A CASE REPORT}

M. Brunner, P. Knöbl, P. Kalhs, K. Machold, W. Graninger, G. Leitner, P. Höcker, K. Lechner, H. Greinix. Vienna, Austria

Background: For patients with systemic lupus erythematosus (SLE) refractory to conventional treatment, high dose immunosuppression and haemopoietic stem cell transplantation have been suggested as an alternative treatment.

Patient: We report on an 18 year old woman diagnosed with SLE at the age of 14 who had been treated with corticosteroids, azathioprine, cyclophosphamide, and immunoadsorption and had repeatedly required mechanical ventilation for lupus pneumonitis. The antinuclear antibody titre was $1 / 640$. Anti-double stranded DNA antibodies and $\mathrm{C} 3 \mathrm{c}$ were $317 \mathrm{IU} / \mathrm{ml}$ and $0.4 \mathrm{~g} / \mathrm{l}$, respectively. On admission she presented with significant impairment of pulmonary function, proteinuria of $11.97 \mathrm{~g} / 24 \mathrm{~h}$, anaemia, thrombocytopenia, and arterial hypertension.

Methods: Autologous haemopoietic stem cells were mobilised with cyclophosphamide $\left(2.0 \mathrm{~g} / \mathrm{m}^{2}\right)$ and G-CSF $(5 \mu \mathrm{g} / \mathrm{kg} /$ day $)$. After leukapheresis a CD34+ selection using the ISOLEX device was performed. After immunosuppression with cyclophosphamide (200 $\mathrm{mg} / \mathrm{kg})$ over four days and ATG $(90 \mathrm{mg} / \mathrm{kg})$ over three days, $8.87 \times 10^{6}$ CD34+ cells were infused.

Results: Myeloid engraftment with an ANC $>0.5 \mathrm{~g} / 1$ and platelet engraftment with a non-transfused platelet count $>20 \mathrm{~g} / 1$ were achieved on days 9 and 8, respectively. Without further complications the patient could be discharged on day 14. During the following weeks 
her antinuclear antibody titre became negative. Anti-double stranded DNA antibodies were reduced to $8.1 \mathrm{IU} / \mathrm{ml}$ on day 40 . C $3 \mathrm{c}$ values dropped to $1.2 \mathrm{~g} / 1$ on day 40 . Proteinuria significantly decreased to $1.37 \mathrm{~g} / 24 \mathrm{~h}$ on day 60

Conclusion: In the investigated patient with advanced SLE haemopoietic stem cell transplantation led to a clinical and serological improvement 60 days after transplantation. How long the response will last, however, has to await further evaluation.

\section{P19 AUTOLOGOUS CD34+ SELECTED HAEMOPOIETIC STEM CELL TRANSPLANTATION (CD34+/HCT) FOR MULTIPLE SCLEROSIS: A SINGLE CENTRE EXPERIENCE}

E. Carreras, A. Saiz, F. Graus, P. Marín, C. Martínez, M. Rovira, T. Arbizu, B. Casanova, J. Berenguer, R. Mazzara, E. Tolosa, E. Montserrat. Barcelona, Valencia, Spain

Patients, methods, and results: We analyse the outcome of the first 10 patients with multiple sclerosis (MS) included in a phase II trial of CD34+/HCT. Blood stem cells were mobilised with cyclophosphamide $(\mathrm{Cy})\left(3 \mathrm{~g} / \mathrm{m}^{2}\right)$ and $\mathrm{G}-\mathrm{CSF}(5 \mu \mathrm{g} / \mathrm{kg} /$ day $)$. CD34+ selection was performed by means of Isolex 300 or Clinimacs system. Conditioning included $\mathrm{BCNU}\left(300 \mathrm{mg} / \mathrm{m}^{2}\right)$, Cy $(150 \mathrm{mg} / \mathrm{kg}$ in 3 days), and ATG (Merieux) (60 mg/kg in 4 days). Patients were assisted in LAF rooms, received low microbial diet, oral ciprofloxacin, fluconazole, and acyclovir, inhaled pentamidine, IV immunoglobulin, and G-CSF.

Between April 1998 and June 2000, 10 patients with secondary progressive (6 cases) or relapsing/remitting (4 cases) MS underwent HCT. Their median (range) age, Kurtzke EDSS and Karnofsky score were 30 years (23-45), 6.25 (5-6.5), and 60 (40-80), respectively. The grafts contained a mean (SD) of $4.8(1.7) \times 10^{6} / \mathrm{kg}$ CD $34+$ cells. Clinimacs selection (8 cases) resulted in a mean of $0.4(0.19) \times 10^{4} / \mathrm{kg}$ CD3+ cells; being 30 and $7 \times 10^{4} / \mathrm{kg}$, respectively in two Isolex procedures. Conditioning related toxicity were grade I mucositis in all patients and grade II liver toxicity in one. During neutropenia all patients presented fever which responded to empirical antibiotic administration. WBC $>500 / \mu 1$ and platelets $>20000 / \mu 1$ were achieved after a median of 10.5 (9-18) and 12 (9-15) days, respectively. One patient had two episodes of CMV infection that responded to ganciclovir. After a median follow up of $15(2-28)$ months, two patients showed an improvement of EDSS (1 and 1.5, respectively) and eight remained stable (including one patient who slightly worsened during HCT). Two patients had relapses after HCT. All episodes were subjective sensory symptoms that lasted for a few days and did not require treatment. No patients needed additional immunosuppressive treatment after HCT.

Conclusion: CD34+/HCT is a feasible approach in MS. To determine whether CD34+/HCT influences the clinical course of patients remains to be seen; further patients and a longer follow up will be required.

\section{P20 HIGH DOSE IMMUNOSUPPRESSIVE TREATMENT AND AUTOLOGOUS STEM CELL TRANSPLANTATION (SCT) OF SEVERE MULTIPLE SCLEROSIS (MS)}

R.A. Nash, G. Kraft, J. Bowen, P. McSweeney, S. Pavletic, J. Al-Omaishi, J. Corboy, H. Openshaw, J. Storek, L. Holmberg, J. Zunt, K. Prather, K. Ryan, K. Sullivan. Seattle, Denver, Omaha, Durate, Durham, USA

Objective: To evaluate the safety and therapeutic efficacy of HDIT and autologous CD34+-selected SCT for severe multiple sclerosis.

Methods: Autologous peripheral blood stem cells (PBSC) were mobilised with G-CSF (16 $\mu \mathrm{g} / \mathrm{kg} /$ day) and CD34 selected. HDIT consisted of total body irradiation (TBI) (800 cGy), cyclophosphamide $(120 \mathrm{mg} / \mathrm{kg}$ ), and horse anti-thymocyte globulin (ATG) $(90$ $\mathrm{mg} / \mathrm{kg}$ ). Eligibility required that patients have an EDSS from 5.0 to 8.0 and deterioration of one or more points over the previous year.

Results: Twenty patients with secondary progressive $(\mathrm{n}=15)$, primary progressive $(n=4)$, or relapsing-remitting $(n=1)$ disease with a median age of 43 (range 27-60) years were enrolled in the study. The median EDSS at HDIT was 7.0 (5.0-8.0). The median follow up has been $5(1-24)$ months. Neutrophil (ANC >500) and platelet $(>20000)$ recovery occurred by $9(8-12)$ days and $8(6-12)$ days after SCT, respectively. Patient No 4 had an MS flare during administration of G-CSF for mobilisation. Patient No 9, the only patient who received rabbit ATG because of a positive skin test to horse ATG, developed an EBV associated lymphoproliferative disorder after transplant and died at day 53. Patient No 16 had a sustained fever of unknown origin and had an increase in the baseline EDSS of 7.5 to 8.5 at 3 months. Thirteen patients were considered evaluable at 3 or more months after transplant. At the last evaluation, 2 patients had an increase of EDSS of at least 0.5 points, 4 patients had a decrease in EDSS of at least 0.5 points, and 7 patients have remained stable. Importantly, no new or enhancing lesions have been seen on MRI of the brain after transplantation except for patient No 4 with the flare of MS. No patient has required further treatment with interferon $\beta$ or copaxone.

Conclusions: Toxicities from HDIT to date have been, in general, manageable and transient. We have added prednisone to the mobilisation regimen to prevent G-CSF related neurological toxicity, and prohibited the use of rabbit ATG. Further follow up is required to assess the outcome more fully.

\section{P21 AUTOLOGOUS PERIPHERAL BLOOD PROGENITOR CELL (PBPC) TRANSPLANTATION IN SEVERE PROGRESSIVE MULTIPLE SCLEROSIS}

R. Saccardi, G.L. Mancardi, A. Bacigalupo, P. Di Bartolomeo, F. Gualandi, G. La Nasa, A. Murialdo, F. Pagliai, F. Papineschi, A.M. Marmont. Florence, Genova, Pescara, Cagliari, Pisa, Italy

Patients and methods: We designed a study mainly directed towards investigating MRI and laboratory changes after autologous PBPC transplantation in patients affected by advanced, poor prognosis and refractory MS. The study was approved by both the Italian Cooperative Group for BMT (GITMO) and the local ethical committee. Patients were mobilised with CTX $4 \mathrm{~g} / \mathrm{m}^{2}$ plus filgrastim $5 \mu \mathrm{g} / \mathrm{kg}$ and conditioned with BEAM followed by rabbit ATG (thymoglobulin $5 \mathrm{mg} / \mathrm{kg}$ at days 1 and 2), according to the Fassas protocol. CyA $1 \mathrm{mg} / \mathrm{kg}$ ev was added during BEAM to prevent cytokine release. Ten patients from 5 centres received a transplant with a median follow up of 8 months (1-24); the procedure was well tolerated and no major serious adverse events were reported.

Results: Febrile neutropenia was shown in 6/10 patients and resolved with empirical ev antibiotic treatment. CMV reactivation was shown in 4/10 patients 15 to 35 days from BMT and was successfully treated with ganciclovir. PMN $<0.5 \times 10^{9} / 1$ and platelets $<50 \times 10^{9} / 1$ were $7(6-12)$ and $8.5(4-18)$ respectively. A marked decrease of all lymphocytic subsets was shown after BMT; circulating CD4+ count remained below the normal range for a longer time than $\mathrm{CD} 8+$, thus resulting in a marked inversion of the CD4+/CD8+ ratio up to 180 . Low CD19+ and CD3/16/56+ counts were also shown. The number of $\mathrm{Gd}$ enhancing lesions started to decrease after the mobilisation treatment and 2-4 months after transplantation dropped to zero.

Conclusions: This regimen was well tolerated but induced a prolonged reduction of a number of circulating lymphocytic subsets, possibly resulting in a CMV reactivation risk. The duration of anti-inflammatory response and the effects on the enlarging and new areas appearing on $T_{2}$ weighted images are still to be clarified.

\section{P22 REVERSAL OF CROHN'S DISEASE AND ITP AFTER PERIPHERAL BLOOD STEM CELL (PBSC) BOOST AND INCREASED DONOR T CELL CHIMERISM AFTER ALLOGENEIC BONE MARROW TRANSPLANT (BMT) FOR APLASTIC ANAEMIA}

H. Hägglund, L. Törkvist, J. Mattsson, P. Ljungman, O. Ringdén Stockholm, Sweden

Patient, methods, and results: A 21 year old man with aplastic anaemia was grafted with $2.3 \times 10^{8} \mathrm{MNC} / \mathrm{kg}$ HLA-identical sibling marrow in November 1995. Conditioning consisted of CY $200 \mathrm{mg} / \mathrm{kg}$ and $10 \mathrm{mg} / \mathrm{kg}$ ATG (thymoglobulin). CsA and MTX were given as GVHD prophylaxis. Two autoimmune manifestations were diagnosed after transplant, Crohn's disease in August 1997 and ITP in October 1997. Remission of Crohn's disease was obtained with steroids. The treatment of thrombocytopenia with steroids, IVIG and splenectomy was unsuccessful. Chimerism studies in September 1998 showed 50\% recipient $\mathrm{T}$ cells. Owing to severe thrombocytopenia and mixed chimerism a booster transplantation of $8.4 \times 10^{8} \mathrm{MNC} / \mathrm{kg}$ donor PBSC after $10 \mathrm{mg} / \mathrm{kg}$ ATG treatment was given in October 1998. The platelet count became normal within a week after the booster procedure and the recipient $\mathrm{T}$ cells were reduced. In May $199910 \%$ of the $\mathrm{T}$ cells were of recipient origin. A colitis was diagnosed in September 1999, the biopsy could not confirm Crohn's disease. The colitis was 
successfully treated with local steroids and 5-ASA (mesalazin). Now, almost 2 years after the booster transplantation, the patient has normal platelets and no signs of Crohn's disease.

Conclusion: We speculate that recipient aberrant $\mathrm{T}$ cells induced aplastic anaemia after BMT, ITP, and Crohn's disease. These autoimmune manifestations were reversed by the donor PBSC booster procedure and healthy donor $\mathrm{T}$ cells.

\section{P23 UNRELATED ALLOGENEIC STEM CELL TRANSPLANTATION IN AN INFANT WITH SEVERE AUTOIMMUNE PANCYTOPENIA ASSOCIATED WITH COELIAC DISEASE: A CASE REPORT}

P. Rohrlich, F. Legrand, A. Faye, J-F. Hugot, M. Duval, E. Vilmer. Paris, France

Background: Severe Evans disease is an uncommon autoimmune disease in children, may be fatal, and other organs are sometimes affected.

Patient: We report the case of a boy who at 9 months of age had diarrhoea, resulting in a failure to thrive and leading to the diagnosis of coeliac disease at 12 months. Immunoglobulin levels were subnormal and IgG directed against gliadin were raised. No cellular or humoral immunodeficiency was diagnosed. Profound thrombocytopenia associated with life threatening autoimmune anaemia occurred at 16 months. Then autoimmune neutropenia appeared at 21 months.

Methods: Initial treatment included high dose steroids, but early relapse and corticodependence led to splenectomy followed by use of various drugs including cyclophosphamide, cyclosporin, and antiCD20 (Mabthera \& No 61650). Despite these treatments no improvement was noted and an allogeneic unrelated BMT was performed at 30 months. The donor was HLA-A, B, DR, DQ matched, with one HLA-C mismatch. Conditioning regimen included busulfan, cyclophosphamide, and ATG.

Results: The early outcome after transplant was uneventful and complete donor chimerism was noted on day 30. Grade II aGVHD occurred, and there was no recurrence of pancytopenia.

Conclusion: Although a longer follow up is needed to confirm the benefit of the BMT procedure in this instance, it appears that allo unrelated BMT is feasible and may be a curative treatment in infants with severe Evans syndrome.

\section{P24 SUCCESSFUL HIGH DOSE CHEMOTHERAPY (HDC) WITH AUTOLOGOUS HAEMOPOIETIC STEM CELL TRANSPLANTATION (SCT) IN TWO PATIENTS WITH BEHÇET'S DISEASE AND PULMONARY INVOLVEMENT}

M. Hensel, R.F. Schlenk, C. Fiehn, A. Breitbart, A.D. Ho. Heidelberg, Ulm, Germany

Background: The prognosis of patients with Behçet's disease and pulmonary involvement is poor. Half of the patients die within three years after the onset of haemoptysis.

Patients: We describe the successful treatment of two patients (aged 30 and 49 years) with Behçet's disease and pulmonary bleeding with HDC and haemopoietic SCT. Both were refractory to conventional immunosuppression with recurrence of disease activity after dose reduction of oral cyclophosphamide (Cy) and prednisone.

Methods: The mobilisation regimen of our pilot trial consists of Cy $2 \mathrm{~g} / \mathrm{m}^{2}$ followed by peripheral blood stem cell harvest during the G-CSF $(10 \mu \mathrm{g} / \mathrm{kg})$ supported haematological reconstitution. If no CD34 positive selection of the peripheral stem cell graft is possible, patients are assigned to a second mobilisation with $\mathrm{Cy} 4 \mathrm{~g} / \mathrm{m}^{2}$ followed by G-CSF and peripheral blood stem cell harvest. Subsequently patients receive melphalan $200 \mathrm{mg} / \mathrm{m}^{2}$ followed by autologous CD34 selected SCT.

Results: Eleven days after the first mobilisation a total of $4.3 \times 10^{6}$ and $2.9 \times 10^{6} \mathrm{CD} 34+$ cells $/ \mathrm{kg}$, respectively, were collected within two leukaphereses. As CD34+ selection was not possible for such concentrations, both patients received a second mobilisation. After 14 and 15 days both patients yielded within 1 and 2 leukaphereses a second stem cell graft and CD34 positive selection was successfully performed, providing $5.8 \times 10^{6}$ and $3.6 \times 10^{6} \mathrm{CD} 34+$ cells $/ \mathrm{kg}$, respectively. In both patients disease manifestations improved during the mobilisation treatment. The side effects of the mobilisation were mild.

Both patients responded very well to the conditioning regimen and SCT. The first patient had complete remission of all symptoms and signs. With a follow up time of 17 months, he is still in complete remission without further drug treatment. In the second patient, high dose melphalan and SCT led to complete resolution of pulmonary infiltrates and most of the other symptoms. Haemolysis disappeared. Nine months after transplantation, prednisone is now tapered to 2.5 $\mathrm{mg} /$ day.

Regimen related toxicity was minimal in both patients (grade I gastrointestinal, no serious infections, no bleeding).

Conclusions: Although follow up is short, our data show that myeloablative chemotherapy with melphalan followed by autologous T cell-depleted SCT was safely used to treat patients with Behçet's disease with a poor prognosis. Whether myeloablative treatment can induce a durable response and improve the prognosis remains unknown.

\section{P25 AUTOLOGOUS STEM CELL TRANSPLANTATION (ASCT) IN CHILDREN WITH PROGRESSIVE SYSTEMIC JUVENILE CHRONIC ARTHRITIS (JCA)}

F. Zintl, A. Köhler, A. Müller, D. Fuchs, A. Sauerbrey, B. Gruhn, J. Oppermann. fena, Germany

Background: Although current approaches for the treatment of the JCA have improved the overall prognosis, functional disabilities occur in $20-30 \%$ of patients, and $5-10 \%$ develop a serious handicap. ${ }^{1}$ ASCT has been proposed as a new therapeutic option for patients with severe autoimmune diseases refractory to conventional treatment. Here, we report two children with a severe form of systemic JCA treated with ASCT.

Patients: The first patient was a 5 year old girl who developed a severe systemic JCA at the age of 2.5 years with high spiking fever, rashes, hepatomegaly, polyarthritis, morning stiffness, inability to walk, ESR $>100 \mathrm{~mm} / 1 \mathrm{st} \mathrm{h}$, and CRP $>100 \mathrm{mg} / \mathrm{l}$. The second child was a 14 year old girl who had had systemic JCA since the age of 1 year with rashes, spiking fever, polyarthritis, morning stiffness, iritis, ESR $>100 \mathrm{~mm} / 1 \mathrm{st} \mathrm{h}, \mathrm{CRP}>100 \mathrm{mg} / \mathrm{l}$, and erosive changes of different joints. Both patients were refractory to conventional treatment with NSAIDs, methotrexate, cyclophosphamide, corticosteroids, and etanercept.

Methods: Stem cell harvest: After a single priming dose of cyclophosphamide $\left(2 \mathrm{~g} / \mathrm{m}^{2}\right)$ and mobilisation with G-CSF at a dose of 10 $\mu \mathrm{g} / \mathrm{kg} /$ day peripheral blood stem cells were collected by the use of a Cobe separator. A Clinimacs device was used to select positively CD34, yielding a final CD 34+ cell amount of $6.5 \times 10^{6} / \mathrm{kg}$ for the first and $4.3 \times 10^{6} / \mathrm{kg}$ for the second child contaminated with zero and $1 \times 10^{4}$ CD3+ lymphocytes, respectively. Stem cells were stored in liquid nitrogen. Conditioning regimen: fludarabine $\left(30 \mathrm{mg} / \mathrm{m}^{2}\right)$ on days -7 and -6 ; cyclophosphamide $(50 \mathrm{mg} / \mathrm{kg}$ ) on days -5 to -2 ; ATG (10 $\mathrm{mg} / \mathrm{kg}$ ) on days -6 to -2 ; methylprednisolone $\left(1 \mathrm{~g} / \mathrm{m}^{2}\right)$ on days -4 to -2 . On day 0 , the frozen CD $34+$ cells were thawed and infused. Prednisolone was tapered after 2 months.

Results: Rapid engraftment of neutrophils $>1.0 \times 10^{9} / 1$ on: days 13 and 11 ; platelets $>20 \times 10^{9} / 1$ on days 6 and 11 ; lymphocytes $>1.0 \times 10^{9} / 1$ on days 60 and 46, respectively. ESR improved to 24/51 and 51/86 $\mathrm{mm} / 1 \mathrm{st} \mathrm{h}$; CRP $<5 \mathrm{mg} / 1$ occurred on day 18 and $28.7 \mathrm{mg} / 1$ on day 100 , respectively. Patients were discharged from hospital on days 26 and 24, respectively without any joint pain or other clinical symptoms.

Conclusions: As was shown in numerous patients who had received autotransplant for malignancies in childhood, the acute risk of mortality due to toxicity or infection is below $1 \%$ in our unit. This was confirmed in two patients with highly active systemic JCA. The hope for the future is that those children will benefit from this new approach.

1 Petty RE. Prognosis in children with rheumatic diseases: justification for consideration of new therapies. Rheumatology 1999;38:73942 .

\section{P26 RELAPSE AFTER AUTOLOGOUS STEM CELL THERAPY (ASCT) IN A PATIENT WITH SYSTEMIC LUPUS ERYTHEMATOSUS (SLE)}

O. Rosen, G. Massenkeil, F. Hiepe, A. Thiel, H. Radtke, E. Gromnica-Ihle, G. Burmester, A. Radbruch, R. Arnold. Berlin, Berlin-Buch, Germany

Patients and methods: Patients with autoimmune diseases refractory to standard and experimental immunosuppressive treatment have been treated with high dose chemotherapy and ASCT in a study initiated in Berlin. ${ }^{1}$ Three patients with SLE have been included so far-two women, aged 27 and 48 years and one man, aged 37 . The 
disease was diagnosed in these patients in 1987, 1993, and 1989, respectively. The trial fulfilled the EBMT/EULAR guidelines for blood and bone marrow stem cell transplants in autoimmune disease with standard conditioning regimen (CY/ATG). CD34+ selection of the leukapheresis was done by CliniMacs. After the haematological reconstitution, the immune system was regularly monitored by 6-parameter flow cytometry and standard serology. The patients have been followed up for 27,23 , and 18 months, respectively.

Results: All patients achieved a complete remission after ASCT. Monitoring of the immune system by flow cytometry during remission showed a low amount of memory $\mathrm{B}$ cells in all patients. The remission is stable in patients 1 and 2 while in the male patient a frank relapse occurred after 17 months (skin, mucosa, and glomerulonephritis, protein $8.4 \mathrm{~g} /$ day). The relapse was characterised by a change in the composition of autoantibodies compared with the state before enrolment into the trial. At relapse, memory B cells had increased from 5 to $10 \%$ compared with previous samples taken during the observation period from the same patient. A considerably high frequency of plasmablasts, characterised by high CD27 expression, was detected.

Conclusion: The shift in the profile of autoantibodies in the relapse in 1 out of 3 SLE patients may indicate a selection of autoreactive cells. Flow cytometry results indicate drastic activation of B cells and differentiation into plasmablasts identical to those of patients with continuing SLE. The efficacy of standard dose immunosuppression after ASCT has to monitored.

1 Arthritis Research 2000;2:327-36.

\section{P27 EFFECT OF AUTOLOGOUS HAEMOPOIETIC STEM CELL TRANSPLANTATION ON SERIAL GADOLINIUM ENHANCED MAGNETIC RESONANCE IMAGING (MRI) IN SEVERE CASES OF MULTIPLE SCLEROSIS}

G. Mancardi, R. Saccardi, A. Murialdo, F. Gualandi, G. La Nasa, F. Papineschi, P. Di Bartolomeso. Genova, Florence, Cagliari, Pisa, Chieti, Milan, Italy

Background: Autologous haemopoietic stem cell transplantation (AHSCT) is being currently explored as a possible alternative treatment in patients with severe multiple sclerosis (MS). Information on the effect of AHSCT on laboratory markers of disease activity such as magnetic resonance imaging (MRI) are, however, lacking.

Patients and methods: In 10 patients with secondary progressive MS showing both an EDSS ranging from 5 to 6.5 and with documented clinical signs of rapid deterioration over the past year, refractory to conventional treatments, peripheral blood progenitor cells were mobilised with cyclophosphamide $4 \mathrm{~g} / \mathrm{m}^{2}$ followed by $\mathrm{G}-\mathrm{CSF} 10 \mu \mathrm{g} / \mathrm{kg}$. The graft was in vivo T depleted with rabbit ATG (5 $\mathrm{mg} / \mathrm{kg}$ at days 1 and 2 ), after the ablative regimen (BEAM). All cases were submitted to serial monthly TD Gd enhanced MRI for a pretreatment period of three months compared with serial monthly TD Gd enhanced MRI for the subsequent 6 month period. Then TD Gd enhanced MR was carried out every three months until month 24 .

Results: We noted in 7 patients who had received a transplant, with at least 6 months of follow up (median 9 months, range 6-24), that the MRI Gd + enhancing lesions completely disappeared in the months following the conditioning regimen. A marked decrease of the number of $\mathrm{Gd}+$ lesions was already apparent after the mobilisation procedure. The clinical condition remained unchanged or slightly improved.

Conclusion: The present data indicate that AHSCT abrogates MRI disease activity in cases of severe secondary progressive MS.

\section{P28 HIGH DOSE CHEMOTHERAPY WITH AUTOLOGOUS BLOOD STEM CELL TRANSPLANTATION FOR TREATMENT OF MULTIPLE SCLEROSIS: CASE PRESENTATION}

P.T. Ledziowski, P.A. Mensah, B. Pitkowska-Jakubas, A.B Skotnicki. Kraków, Poland

Patient and methods: Secondary progressive disease was confirmed in a 41 year old patient with multiple sclerosis diagnosed 20 years ago. His clinical state was estimated as 6.0 points in the 10 -step Kurtzky scale (EDSS). The patient was referred to the department of haematology in June 1999 for stem cell mobilisation. PBSC were mobilised with cyclophosphamide $4 \mathrm{~g} / \mathrm{m}^{2}$ followed by G-CSF $10 \mu \mathrm{g} / \mathrm{kg}$. PBSC were manipulated by CD34 selection (SuperMACS) $-2.3 \times 10^{6}$ CD34+ cells/kg were infused after HDCT. BEAM (carmustine, vepesid, cytosine arabinoside, melphalan) was used as a conditioning regimen and was followed by anti-thymocyte globulin (ATG) at days 1 and 2. Fever and upper gastrointestinal bleeding complicated the immediate post-transplant course. The aplastic period lasted 14 days.

Results: Complete haematological reconstruction was achieved at day 14 for granulocytes $(>1.0 \mathrm{~g} / \mathrm{l})$ and day 21 for platelets $(>20 \mathrm{~g} / \mathrm{l})$. From day 8 the patient had recurrent fever with negative blood cultures. At day 38 progressive respiratory failure with bilateral alveolar infiltrations in chest $x$ ray was confirmed. Mechanical ventilation was used with good results-quick regression of infiltrative changes. The disease has not progressed after 12 months' observation.

Conclusion: High dose chemotherapy followed by autologous blood stem cell transplantation may by an option for patients with progressive multiple sclerosis. Long term follow up will be necessary to demonstrate whether the lack of progression persists. Effective depletion of $\mathrm{T}$ cells may be connected with delayed immunological recovery after transplantation and an increased risk of infections.

\section{P29 FLUDARABINE BASED CONDITIONING FOLLOWED BY AUTOLOGOUS BLOOD AND MARROW TRANSPLANTATION IN SEVERE AUTOIMMUNE} DISEASES

M.A. Andolina, M.R. Rabusin, L.L Lepore, N. Maximova, S.P. Parco. Trieste, Italy

Background: Intensive immunosuppression followed by autologous haemopoietic stem cell transplantation has been proposed as an effective treatment for severe and refractory autoimmune diseases. Especially in adults, this procedure resulted in longlasting remission but was associated with a mortality of $10 \%$ and even $20 \%$ in a group of children with juvenile chronic arthritis.

Patients and methods: Previously we carried out transplants in 10 patients with severe autoimmune disease with a non-myeloablative conditioning regimen based on cyclophosphamide and antilymphocytic serum (ALG); the procedure was well tolerated achieving some long remission. More recently, we used a different conditioning regimen based on fludarabine $30 \mathrm{mg} / \mathrm{m}^{2} /$ day for 5 days and ALG 5 vials $/ \mathrm{m}^{2} /$ day for 5 days, followed by the infusion of blood and marrow cells treated ex vivo with vincristine and methylprednisolone. To date we have treated 9 patients $(2 \mathrm{M}, 7 \mathrm{~F}$, median age 23 years, range 4-45) with severe diseases not responding to conventional treatment (2 JCA, 1 MS, 1 PRCA, 1 RA, 1 Sjögren's syndrome, 1 Behçet's disease, 1 ITP, and 1 multiple autoimmune disorder). After a median follow up of 15 months (range 7-23) 3 patients are in complete remission, 4 in partial remission, while 2 show no improvement. As compared with other protocols our conditioning regimen is not myeloablative; the patients did not have any consequences of complete myeloablation of haemopoietic tissue - they did not require blood transfusion and spent only a short time in hospital.

Conclusions: These preliminary results seem to show that a longlasting remission is achievable after a non-myeloablative fludarabine based conditioning regimen. A larger controlled trial with and without infusion of autologous cells is needed.

\section{P30 THYMIC RESPONSE TO LYMPHODEPLETING TREATMENTS IN RHEUMATOID ARTHRITIS}

F. Ponchel, S. Bingham, S. Douglas, P. Emery, J. Isaacs. Leeds, UK

Background: Lymphocytotoxic treatments, such as depleting monoclonal antibody (mAb) treatment and autologous stem cell transplantation (ASCT), are employed in severe rheumatoid arthritis (RA). An initially unpredicted "side effect" of these treatments was prolonged peripheral blood lymphopenia, and the dogma has arisen that this reflects poor thymic function. It is now possible to define recent thymic emigrants. During their passage through the thymus, $\mathrm{T}$ cell precursors rearrange their $\mathrm{T}$ cell receptor genes, which involves the excision of segments of DNA and produces small circles of episomal DNA (TRECs). As these naive cells expand in the periphery, TRECs do not replicate but are distributed among daughter cells and are gradually diluted in the peripheral $\mathrm{T}$ cell pool. We quantified TRECs as a surrogate of thymic activity in peripheral blood of patients undergoing high dose lymphocytotoxic treatment with stem cell rescue.

Method: Flow cytometry was used to isolate the most immature circulating $\mathrm{T}$ cells (CD45RBbright, CD45RA+, CD45ROdull, CD62Lhigh). A real time PCR assay was developed to measure the number of CD4+ and CD8+ $\mathrm{T}$ cells within this subset containing a TREC. 
Patients: Six patients with RA undergoing high dose cyclophosphamide treatment with autologous stem cell rescue. Longitudinal blood samples were collected for up to 2.5 years after treatment. Clinical results on these patients are presented by $S$ Bingham.

Results: All patients showed some evidence of thymic activity after treatment, though this was insufficient to reconstitute fully the peripheral $\mathrm{T}$ cell pool. Thus all patients remained CD4+ lymphopenic during 2.5 years of follow up. Patients who exhibited sustained thymic activity also showed a small rise in naive CD4+ counts. In most patients, however, the most naive subset of CD4+T cells remained stable over time, and surface phenotyping suggested that recent thymic emigrants (defined as TREC-containing cells) rapidly differentiated. Thymic activity was inversely correlated with levels of inflammation (CRP). The use of cyclosporin A appeared to suppress thymic activity but this remains to be clarified.

Conclusion: We have shown evidence of thymic activity in patients with RA. After lymphocytotoxic chemotherapy this contributes to peripheral blood reconstitution, but inflammation and immunosuppression may both impair thymic function after ASCT. We continue to analyse these patients in detail, but our current assessment is that their level of thymic activity is inadequate for full $\mathrm{T}$ cell reconstitution.

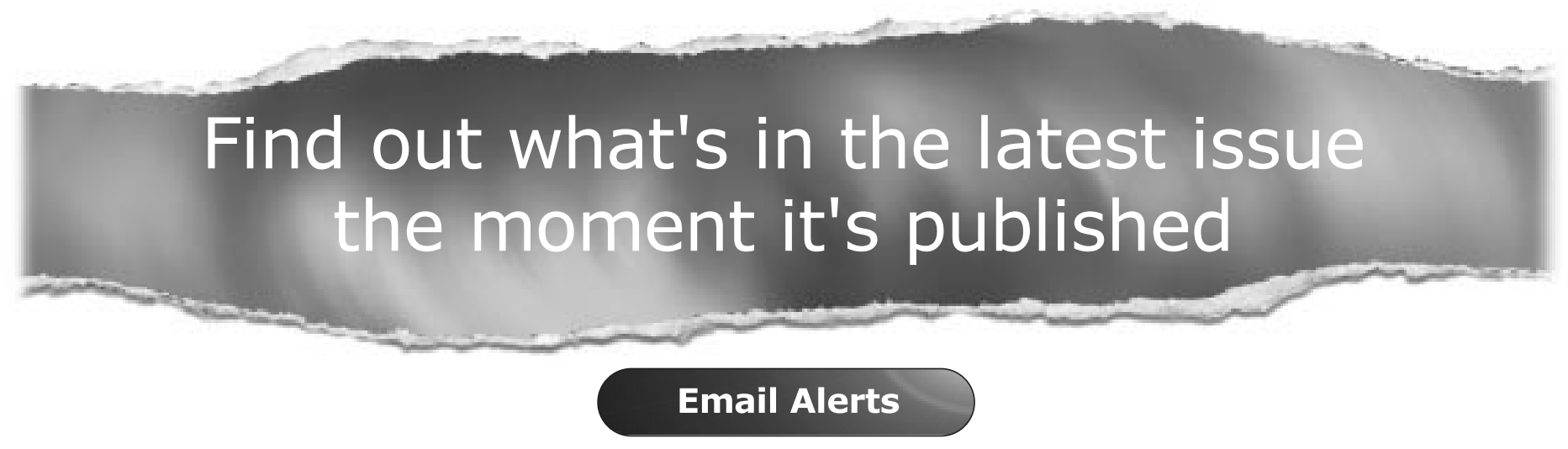

Sign up to receive the table of contents by email every month. You can select from three alerts: Table of Contents (full), TOC Awareness (notice only); Annals of the Rheumatic Diseases related announcements.

\section{www.annrheumdis.com}

